3 Hollander D. The intestinal permeability barrier A hypothesis as to its regulation and involvement in Crohn's disease. Scand $\mathcal{F}$ Gastroenterol 1992; 27: 721-6.

4 Teahon K, Menzies IS, Bjarnason I. Importance of molecular geometry on permeation rates of in vivo permeability probes. Gut 1992; 33 (suppl 1): 557.

5 Philipsen EK, Batsberg W, Christensen AB. Gastrointestinal permeability to polyethylene Gastrointestinal permeability to polyethylene
glycol: an evaluation of urinary recovery of an glycol: an evaluation of urinary recovery of an
oral load of polyethylene glycol as a parameter oral load of polyethylene glycol as a parameter

6 Iqbal TH, Lewis KO, Cooper BT. Diffusion of polyethylene glycol-400 across lipid barriers in vitro. Clin Sci 1993; 85: 111-5

7 Maxton DG, Bjarnason I, Reynolds AP, Catt SD, Peters TJ, Menzies IS. Lactulose, 51 Cr-labele ethylenediaminetetra-acetate, L-rhamnose and polyethyleneglycol 500 as probe markers for assessment in vivo of human intestinal permeability. Clin Sci 1986; 71: 71-80.

\section{Echinococcus of the liver}

EDITOR,-We read with interest Dr Morris's leading article on echinococcus of the liver (Gut 1994; 35: 1517-8).

We were surprised to read that percutaneous aspiration entailed a high risk of fluid leakage and anaphylaxis. Published reports do not support this view.

In Filice's report ${ }^{1}$ on five patients successfully treated by percutaneous aspiration and $95 \%$ alcohol injection, no complications were noted.

Two series were reported by Khuroo et al. The first ${ }^{2}$ involved 12 patients with 21 cysts, no anaphylaxis was reported, one patient had reversible urticaria and two antibiotic responsive cyst infection. The second study ${ }^{3}$ of 33 cysts was prospective and randomised comparing albendazole and percutaneous drainage and a combination of both. Twenty two aspirated cysts showed significant size reduction and change in echopattern compared with two in the albendazole group. Maximum size reduction was achieved in cysts treated with albendazole and percutaneous drainage. No patient suffered anaphylaxis, two had urticaria, two cyst infections, three developed fever, and one had biliary rupture.

We have reported our experience ${ }^{4}$ with percutaneous drainage of 14 cysts. To decrease the risk of peritoneal spillage, cysts were approached under ultrasound guidance through thick normal liver parenchyma and initially decompressed by fine (20 gauge) needle aspiration. Pigtail (8.3 French) catheters were subsequently used for $20 \%$ saline lavage and $95 \%$ alcohol injection. All cysts showed significant shrinkage during a mean follow up of 9.6 months A single episode of reversible anaphylaxis was seen and average hospital stay was 48 hours.

We acknowledge the limitations of curren studies, mainly the small patient numbers and lack of longterm follow up. We believe, however, that the technique is a valuable cost effective addition to treatment. It should be undertaken by experienced hands under intensive monitoring and is particularly attractive in high operative risk patients and those with recurrent disease after surgery.

C AZAR

Division of Hepatology and Gastroenterology Hôpital Sainte-Marguerite,

Marseille,

Correspondence to: C Azar, Department of Gastroenterology, Erasme Hospital, Route de Lennik 808, 1070 Brussels, Belgium.
1 Filice C, Pirola F, Brunetti E, Dughetti S Strosselli M, Foglieni Scotto C, et al. A new therapeutic approach for hydatid liver cysts. Gastroenterology 1990; 98: 1366-8.

2 Khuroo MS, Zargar SA, Mahajan R Echinococcus granulosus cysts in the liver: management with percutaneous drainage. Radiology 1991; 180: 141-5.

3 Khuroo MS, Dar MY, Yattoo GN, Zargar SA Javaid G, Ahmad K, et al. Percutaneous drainage versus albendazole therapy in hepatic drainage versus albendazole therapy in hepatic hydatidosis: a prospective, randomizec
Gastroenterology 1993; 104: 1452-9.

4 Bastid C, Azar C, Doyer M, Sahel J. Percutaneous treatment of hydatid cysts unde sonographic guidance. Dig Dis Sci 1994; 39: 1576-80.

\section{BOOK REVIEWS}

Familial adenomatous polyposis and other polyposis syndromes. Edited by $R$ K S Phillips, A D Spigelman, J P S Thomson. (Pp 234; illustrated; £65.00.) London: Edward Arnold, 1994. ISBN 0340 567554.

Just as Marks is to Spencer, so St Mark's is to polyposis. The condition may have remained the same but only recently has the term familial adenomatous polyposis (FAP) become common currency. It has evolved through stages variously as familial polyposis coli, familial multiple polyposis, multiple intestinal polyposis, familial adenomatosis coli, familial polyposis coli - and just about every other combination of the terms - until arriving at its latest form. Indeed, in the way that terminological difficulties are now resolved, a meeting of 30 of the great and good in colonic polyps from 11 countries met at Leeds Castle in June 1985 to resolve the nomenclature. Those Euro-sceptics among the gastroenterological community might be distressed to learn that the horizon of polyposis groups has now extended from a castle in Kent to Euro-FAP, which is supported financially by the European Union.

It is obviously worthy that such experts in a comparatively rare condition should come together to share their experiences, data and, above all, their patient bases. It must be recognised, however, that all of the fundamental work in setting up registries, which has proved such a fruitful foundation for research, have come from the effort of three people who worked at St Mark's Hospital: LockhartMummery, Dukes, and (at that time) Dukes's junior laboratory technician - Bussey. The tribute that the editors of this present volume pay to Bussey is clearly justified by his enormous and meticulous contribution, especially in establishing the St Mark's Polyposis Register (in 1924 or 1925 , there is some uncertainty). The homage to Bussey is made abundantly clear in the preface and generous foreword. The other name that towers throughout this book is that of Gardner, who sadly died some six years ago at the very time that molecular biology was coning in on the gene defect in Gardner's syndrome. The interesting suggestion is made here that, as a mark of respect and acknowledgment of their contributions, familial adenomatous polyposis might be renamed Bussey-Gardner polyposis. It would certainly be a fitting memorial but I just wonder how easy it would be to eradicate the familial and polyposis from the title of the condition and, of course, although the edges of Gardner's syndrome have become somewhat blurred in recent years, it does stand as a fairly established entity. As St Mark's Hospital closes its doors and moves to new pastures within Northwick Park Hospital elsewhere in London, I would have thought there was a good case to be made for renaming the condition St Mark's syndrome.

This is a superb book, which has been lovingly edited by three of the senior surgical staff at St Mark's Hospital. Their affection for those involved in the history of this condition, as well as their current enthusiasm for their subject, permeates through every page and surely none can challenge the credentials or the authority of any of the people involved with this monograph. The history, pathology, genetic, and clinical evaluation of patients are covered in separate chapters. All are readable, and the chapter on genetics is particularly clear. As with all the very best of British surgical teaching, anecdote abounds. Indeed, the potential benefit of such embellishments to teaching are not restricted to surgeons: there is an exceptionally witty parody of Lewis Carroll's Father William as applied to polyposis and was penned by Cuthbert Dukes. I think this is good enough to share with Gut's readers.

'You are old, Father William,' the young surgeon said,

'And your colon from polyps is free.

Yet most of your sibling are known to be dead -

a really bad family tree.'

'In my youth,' Father William replied with a grin,

'I was told that a gene had mutated,

That all who carried this dominant gene

To polyps and cancer were fated.'

'I sought for advice from a surgical friend, Who sighed and said, 'Without a doubt Your only escape from an untimely end

Is to have your intestine right out.'

'It seemed rather bad luck - I was then but nineteen -

'So I went and consulted a quack,

Who took a firm hold on my dominant gene

And promptly mutated it back.'

'This,' said the surgeon, 'is something quite new

And before we can ascribe any merit

We must see if the claims of the fellow are true,

And observe what your children inherit!'

If this book has a fault, it is that the last 60 odd pages are devoted to 'other polyposis syndromes'. Inevitably, this does not have the depth of the earlier chapters on FAP, and mentions some of the cancer family syndromes, which are, of course, strict 'nonpolyposis cancer syndromes'. I think this departure does perhaps illustrate the difficulties of not knowing quite where to stop in the search to be comprehensive.

I cannot believe there is a single practising gastroenterologist who would not benefit from studying this book.

IAN FORGACS

This title may be purchased from the distributor: Oxon OX14 4TD. Tel: 01235 400403; fax: 01235 821511. 